\title{
Human papillomaviruses and the genital tract: old virus, new developments
}

\section{Pathogenesis}

Papillomaviruses are classified with polyomaviruses and SV40 in the family Papovaviridae. All are small viruses with a circular double-stranded DNA genome c. $8 \mathrm{~kb}$ in length which utilises all three forward reading frames. ${ }^{1}$ The genome is transcribed and differentially spliced to produce early proteins (E1-E7) and late proteins (L1 and L2) (fig. 1). The early gene products are non-structural proteins that control viral replication and, in some cases, oncogenicity. The late gene products are structural proteins which make up the virus capsid. DNA sequence analysis of the many papillomaviruses known to infect vertebrates suggests that they belong to an ancient genus which co-evolved with vertebrates. About 70 human papillomavirus (HPV) types have been differentiated by sequence analysis $^{2}$ (fig. 2). Unlike polyomaviruses, most papillomaviruses infect epithelia only. Different types often display tropisms for different epithelial surfaces and c. 20 human papillomaviruses characteristically infect mucosal epithelia, particularly of the genital tract. Epithelial cells are not lysed by infecting HPV; in fact, for productive infection the cell must undergo normal maturation. ${ }^{3}$ Thus, progeny virions are produced only near the mucosal surface and little, if any, viral protein is produced in the basal layers of infected epithelium.

This unique mechanism helps to explain the problems of in-vitro papillomavirus culture, which are only now being overcome with "organotypic rafts" on which keratinocytes are induced to mature. ${ }^{4}$ It also may explain in part the long latency and immune evasion that are characteristic of infections caused by HPV, e.g., warts. Even with treatment, warts are persistent. In our clinic, $39 \%$ of male and $22 \%$ of female patients presenting for the first time with genital warts were still infected after treatment for 6 months. ${ }^{5}$ Destruction of macroscopic warts does not remove HPV, which continues to replicate subclinically in the basal layer. ${ }^{6,7}$ When wart regression eventually occurs, there is histological evidence of a local cell-mediated immune response with $\mathrm{T}$ lymphocytes invading the epithelium. $^{8}$

\section{Carcinogenesis}

Warts are an unsightly but not life-threatening infection. It is the role of HPV in carcinoma of the cervix and in other anogenital malignancies that has fuelled the intense research interest in HPV. ${ }^{9}$ The progressive application of molecular biology tech- niques in recent years has established that DNA from HPV of certain oncogenic genital types, principally types 16 and 18 , is present in nearly all cells derived from cervical cancers as well as in a large proportion of anal, vulval and penile carcinomas. Viral DNA in an infection, such as a wart, is episomal and remains circular, but viral DNA in malignant cells is usually truncated, linear and integrated into the host DNA. Such DNA cannot support a productive infection since the reading frames for structural proteins are lost. However, certain early proteins are overexpressed and the interaction between these and host proteins is intimately involved in the transformation to malignancy. For example, two viral proteins, E6 and E7, bind to and inhibit two key cellular antioncogenes, p53 and retinoblastoma protein $(\mathrm{Rb}) .{ }^{10} \mathrm{In}$ normal cells, $\mathrm{p} 53$ and $\mathrm{Rb}$ regulate cell cycling and apoptosis; their abrogation in cell lines leads to immortalisation. Interestingly, only E6 and E7 proteins from oncogenic HPVs, such as types 16 and 18 , seem to have high affinity for binding these antioncoproteins; E6 and E7 proteins from HPV types 6 and 11, the common types associated with benign anogenital warts, cannot bind anti-oncoproteins, or do so only with low affinity and these types are not found in malignant carcinomas. More recently, another viral protein, E5, has been shown to prevent the presentation of peptides by HLA class 1 by inhibiting a precursor of transporter associated with antigen presentation (TAP) protein. ${ }^{11}$ This may underlie the mechanism by which cervical carcinoma cells evade immune recognition even when foreign (viral) protein is expressed and the cells are invading subepithelial tissues. ${ }^{12}$

\section{Consequences for the population}

The link between oncogenic HPV and anogenital malignancy is supported by a recent longitudinal cohort study of 241 women followed closely over a 2year period by cervical cytology, colposcopy and HPV DNA detection in cervical swabs. ${ }^{13}$ Initially, all patients had normal colposcopy and cytology findings. However, $28 \%$ of women who acquired detectable HPV DNA during follow-up developed cervical intraepithelial neoplasia (CIN) grade 2-3 (moderate to severe dysplasia) within 2 years; only $3 \%$ of women who remained HPV "negative" developed CIN 2-3. Some women developed CIN 2-3 following the detection of "benign" HPV types, but the relative risk was 
Frame 1

\begin{tabular}{|l|l|}
\hline$E 7$ & $E 1$ \\
\hline
\end{tabular}

L1

Frame 2

E6

E2

Frame 3
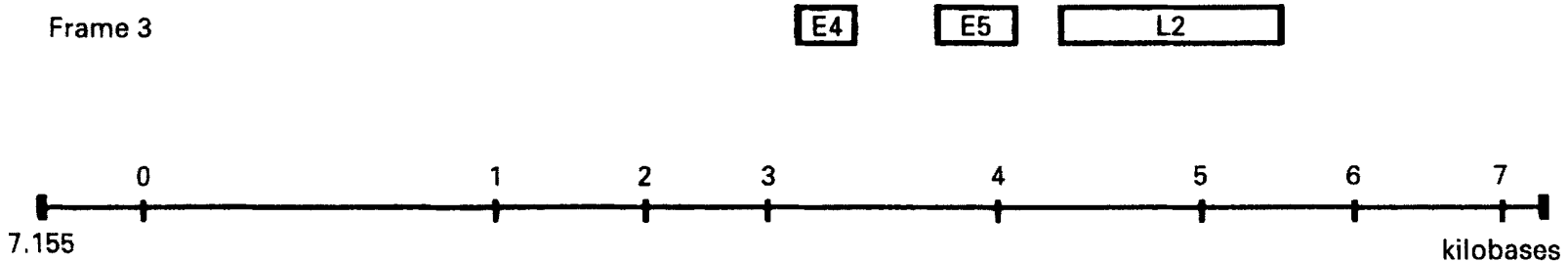

Fig. 1. Genome of HPV

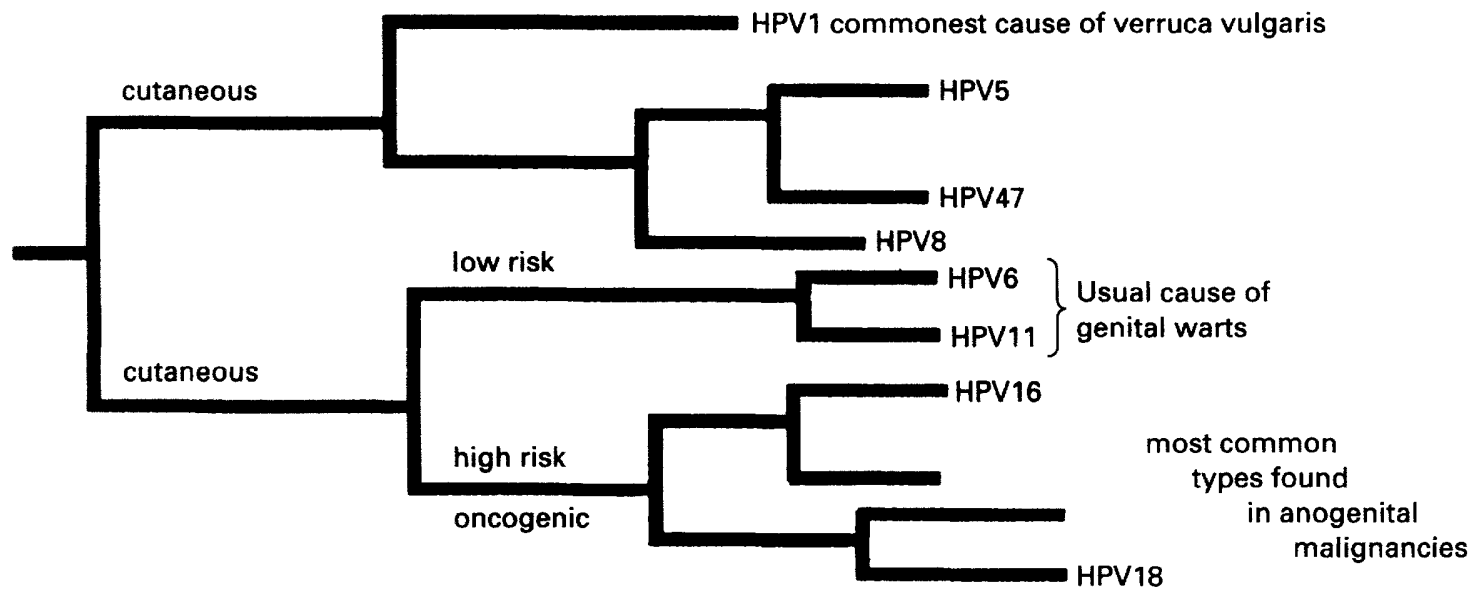

Fig. 2. HPV phylogenetic tree based on comparative DNA sequences (modified after van Ranst et al. ${ }^{2}$ ).

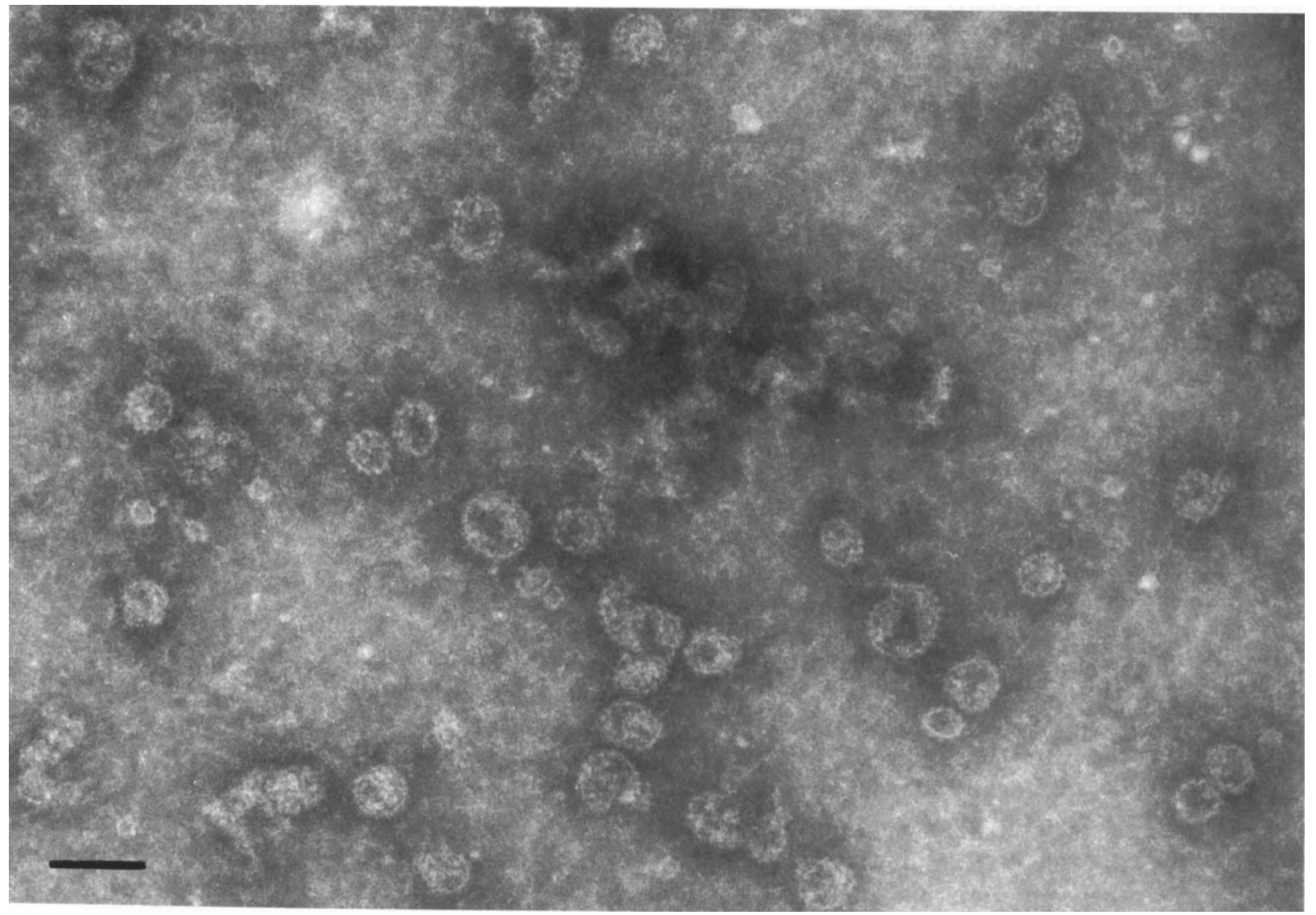

Fig. 3. Pleomorphic HPV capsid-like particles produced from a baculovirus-HPV $11 \mathrm{~L} 1$ recombinant (kindly provided by $\mathrm{N}$. Christensen ${ }^{21}$ ). $\mathrm{Bar}=100 \mathrm{~nm}$ 
much higher when oncogenic HPV types were involved. Similar cohort studies, as well as casecontrolled studies, are now being completed worldwide. ${ }^{14}$ Although the proportions of HPV types contributing to attributable risk differ slightly in different areas, HPV 16 and 18 are by far the commonest carcinogenic types in all areas.

How common is infection with HPV types 16 and 18 in the general population? HPV DNA was detected by PCR in $46 \%$ of cervical swabs taken from 467 college students,${ }^{15} 33 \%$ were type 16 or 18 . Other large-scale surveys have confirmed high prevalences in the general population, much higher than the prevalence of CIN ( $<1 \%$ of the population). PCR-based methods may be too sensitive, detecting a subclinical level of infection that rarely if ever causes disease. With quantitative PCR, significant dysplasia was shown to be associated almost invariably with higher levels of HPV DNA. ${ }^{16}$ These findings support the use of HPV DNA detection as an objective method of cervical screening ${ }^{17}$ and already a number of commercial kits are being developed.

\section{$H P V$ serology and vaccine development}

Another approach to screening is the development of serological tests for HPV. Early attempts to develop HPV serology were frustrated by the difficulty of obtaining satisfactory antigens as in-vitro culture of HPV was impossible. Bacterial-HPV fusion proteins

\section{References}

1. de Villiers E-M. Heterogeneity of the human papillomavirus group. J Virol 1989; 63: 4898-4903.

2. Van Ranst M, Kaplan JB, Burk RD. Phylogenetic classification of human papillomaviruses: correlation with clinical manifestations. J Gen Virol 1992; 73: 2653-2660.

3. Schneider A, Koutsky LA. Natural history and epidemiological features of genital HPV infection. In: Muñoz N, Bosch FX Shah KV, Meheus A (eds) The epidemiology of cervical cancer and human papillomavirus (IARC Scientific Publication 119). Lyons, IARC. 1992: 25-52.

4. Meyers C, Frattini MG, Hudson JB, Laimins LA. Biosynthesis of human papillomavirus from a continuous cell line upon epithelial differentiation. Science 1992; 257: 971-973.

5. Birley HDL, Kupek E, Byrne M, Whitaker L, Renton AM. Clinical features and outcome of anogenital warts in men and women. J Eur Acad Dermatol Venereol 1994; 3 : 198-205.

6. Rymark P, Forslund O, Hansson BG, Lindholm K. Genital HPV infection not a local but a regional infection: experience from a female teenage group. Genitourin Med 1993; 69: 18-22.

7. Ferenczy A, Mitao M, Nagai N, Silverstein SJ, Crum CP. Latent papillomavirus and recurring genital warts. $N$ Engl $J$ Med 1985; 313: 784-788.

8. Coleman N, Birley HDL, Renton AM et al. Immunological events in regressing genital warts. Am J Clin Pathol 1994; 102: $768-774$.

9. zur Hausen H. Human papillomaviruses in the pathogenesis of anogenital cancer. Virology 1991; 184: 9-13.

10. Inman GJ, Cook ID, Lau RKW. Human papillomaviruses, tumour suppressor genes and cervical cancer. Int J STD AIDS 1993; 4: 128-134.

11. Banks L. A review of recent developments. Papillomavirus Report 1994; 5: 187-189. gave disappointing results, perhaps because of prokaryotic translation or cross-reaction with serological responses to ubiquitous skin warts. However, these limited experiments did suggest a type-specific HPV serological response. HPV 11 virions have been obtained from a xenograft model (a wart implanted into the renal capsule of nude mice) and patients with genital warts have significantly increased antibody responses to these virions compared to control patients. ${ }^{18}$ More recently, investigators have used recombinant viruses to express HPV proteins in eukaryotic cells. ${ }^{19,20}$ Recombinant HPV 11 capsids, produced by a baculovirus expression system (fig. 3) can function as an antigen and, perhaps more importantly, as an immunogen inducing high titres of antibodies that will prevent infection by native HPV 11 virus in the xenograft system. ${ }^{21}$ These results seem to signify a significant step towards the development of recombinant HPV vaccines which are currently being evaluated in animal models. ${ }^{22}$

The application of new molecular techniques may make virologists as important as cytopathologists in screening for cervical cancer and will hopefully result in vaccines which will reduce significantly the incidence of the disease.

\section{H. D. L. BIRLEY \\ C. A. HART}

S. N. STACEY*

Department of Medical Microbiology and Genitourinary Medicine, University of Liverpool, P.O. Box 147, Liverpool L69 3BX and * Division of Molecular Biology, Patterson Institute, Christie Hospital, Manchester M29 9BX

12. Cromme FV, Meijer CJLM, Snijders PJF et al. Analysis of MHC class I and II expression in relation to presence of HPV genotypes in premalignant and malignant cervical lesions. Br J Cancer 1993; 67: 1372-1380.

13. Koutsky LA, Holmes KK, Critchlow CW et al. A cohort study of the risk of cervical intraepithelial neoplasia grade 2 or 3 in relation to papillomavirus infection. $N$ Engl J Med 1992 ; 327: 1272-1278

14. Muñoz N, Bosch FX. HPV and cervical neoplasia: review of case-control and cohort studies. In: Muñoz N, Bosch FX, Shah KV, Meheus A (eds) The epidemiology of cervical cancer and human papillomavirus (IARC Scientific Publication 119). Lyons, IARC. 1992: 251-261.

15. Bauer HM, Greer CE, Chambers JC et al. Genital human papillomavirus infection in female university students as determined by a PCR-based method. JAMA 1991; 265 : $472-477$.

16. Mansell ME, Ho L, Terry G, Singer A, Cuzick J. Semiquantitative human papillomavirus DNA detection in the management of women with minor cytological abnormality. Br J Obstet Gynaecol 1994; 101 : 807-809.

17. Sherman ME, Schiffman MH, Lorincz AT et al. Toward objective quality assurance in cervical cytopathology: correlation of cytopathologic diagnoses with detection of high-risk human papillomavirus types. Am J Clin Pathol 1994; 102: 182-187.

18. Bonnez W, Da Rin C, Rose RC, Reichman RC. Use of human papillomavirus type 11 virions in an ELISA to detect specific antibodies in humans with condylomata acuminata. J Gen Virol 1991; 72: 1343-1347.

19. Zhou J, Sun XY, Stenzel DJ, Frazer IH. Expression of vaccinia recombinant HPV16 L1 and L2 ORF proteins in epithelial cells is sufficient for assembly of HPV virion-like particles. Virology 1991; 185: 251-257.

20. Kirnbauer R, Hubbert NL, Wheeler CM, Becker TM, 
Lowy DR, Schiller JT. A virus-like particle enzyme-linked immunosorbent assay detects serum antibodies in a majority of women infected with human papillomavirus type 16. J Natl Cancer Inst 1994; 86: 494-498.

21. Christensen ND, Höpfl R, DiAngelo SL et al. Assembled baculovirus-expressed human papillomavirus type $11 \mathrm{Ll}$ capsid protein virus-like particles are recognized by neutralizing monoclonal antibodies and induce high titres of neutralizing antibodies. $J$ Gen Virol 1994; 75: 2271-2276.

22. Brandsma JL. Animal models for HPV vaccine development. Papillomavirus Report 1994; 5: 105-111. 